\title{
Factors Determining the Usefulness of Mobile Educational Applications: A Review
}

\author{
Emmanuel O.C. Mkpojiogu ${ }^{1}$, Fazillah Mohmad Kamal' ${ }^{2}$ Ebere Anastasia Tochukwu ${ }^{3}$, Azham Hussain ${ }^{4}$ \\ ${ }^{1}$ School of Computing, Universiti Utara Malaysia, 06010 UUM, Sintok, Malaysia; \\ Department of Computer and Information Technology, Veritas University, Abuja, Nigeria \\ ${ }^{2}$ School of Quantitative Sciences, Universiti Utara Malaysia, 06010 UUM, Sintok, Malaysia, \\ fazillah@uum.edu.my \\ ${ }^{3}$ Faculty of Education, Veritas University, Abuja, Nigeria \\ ${ }^{4}$ School of Computing, Universiti Utara Malaysia, 06010 UUM, Sintok, Malaysia
}

\begin{abstract}
The production of mobile educational applications has made it possible for teachers to gain more insight on their various domains. The educational system around the world has gone through a lot of changes within the last decade. These changes undoubtedly, are made possible by the numerous mobile educational applications which are used to enhance teaching and learning. Hence, the purpose of this paper is to identify the factors determining its usefulness. There are several literatures relating to the use of mobile educational applications, however, these literatures do not sufficiently address the factors determining the usefulness of mobile educational applications. Therefore, this research attempted to review the available literatures with the aim of capturing these factors. This study applied systematic literature methodology in order to achieve the stated research goal. Seventy-eight (78) papers in the area of the usefulness of mobile educational applications and factors determining the usefulness of mobile educational They downloaded software. Fourty-three (43) of the most important studies were selected for review from these articles in order to extract the necessary information needed for the study. Although there are few literatures that identified the factors determining the usefulness of mobile educational application, the result revealed that the quality and reliability of the application, important and viable futures of the mobile application, proper monitoring and optimal performance were found to be part of the factors. The research findings indicate that mobile educational applications are useful in enhancing teaching and learning as well as providing satisfaction to users. It also identified factors that determine its usefulness such as quality and reliability of the application and learning the procedures for the use of mobile educational apps. The findings of the research will help administrators, teachers, and policy makers to draw more insight on the best strategies used to promote teaching and learning using mobile educational apps.
\end{abstract}

Key words: Mobile educational applications, usefulness, mobile learning apps

\section{INTRODUCTION}

In this $21^{\text {st }}$ century, students are more driven towards using mobile phones for different reasons but particularly for learning and understanding what is being taught (Roy, 2017). The production of mobile educational applications has made it possible for teachers to gain more insight on their various domains. There is no doubt that $21^{\text {st }}$ century teachers teach with ease even from their homes (Buck, McInnis \& Randolph, 2013). The educational system around the world has gone through a lot of changes within the last decade (Gundala, 2016). Gundala (2016) also posit that these changes undoubtedly, are made possible by the numerous mobile educational applications which are used to enhance teaching and learning. These are made possible through the use of mobile learning or educational applications (Hussein et al., 2019, Hussain et al., 2019; Hussain \& Mkpojiogu, 2017; Hussain et al., 2017; Hussain et al., 2016; Ghani et al,. 2019). A mobile app is a software program one can download and access directly using phones or other mobile devices, like a tablet. It is an application software designed to run on insightful phones, tablet computers and other mobile devices (Inukollu, Keshamoni, Kang \& Inukollu, 2014).The importance of mobile educational applications in our everyday life and activities, particularly in teaching and learning cannot be over emphasized. Notwithstanding the amazing level of development and circulation of mobile educational applications, there are numerous factors that influence its usefulness, but very little has been studied about these determining factors (Kang, 2014; Alrasheedi \& Capretz, 2018). If the factors that influence the usefulness of mobile educational applications are not brought to the knowledge of people, in future, users might remain ignorant of the fantastic benefits of mobile educational applications. Therefore, this paper examines the importance and various factors that determine the usefulness of mobile educational applications.

Prior researches show that mobile educational or learning applications are very useful to users in numerous ways. Very few researches explored the factors that determine their 
usefulness. Hence, there are many factors determining the usefulness of mobile educational applications which have not been discussed in literatures (Kang, 2014; Alrasheedi \& Capretz 2018). The objectives of this study include: i) to examine the usefulness of mobile educational or learning application; ii) to ascertain the various factors determining the usefulness of mobile educational applications. The following are research questions guiding this study: i) what is the usefulness of mobile educational applications?; ii) what are the factors determining the usefulness of mobile educational applications? The purpose of this research is to ascertain the usefulness of mobile educational applications and to discover the various factors determining the usefulness of mobile educational applications so as to contribute towards enhancing effective teaching and learning. This study identified factors that determine the usefulness of educational apps such as quality and reliability of the applications and learning the procedures for the use of mobile educational apps. The findings of the research will help administrators, teachers, and policy makers to draw more insight on the best strategies used to promote teaching and learning using mobile educational apps. This paper would cover various literatures on mobile learning or educational applications between 2004 and 2019. The paper is organized as follows: following section one which is the introduction, is section two, literature review. This is followed by section three, the methodology, and the section four, the results, then follows section five, the discussion of findings and lastly section six, the conclusion and future work.

\section{LITERATURE REVIEW}

The importance of researching on the factors determining the usefulness of mobile learning is crucial. Currently, most existing literatures emphasize on the importance of mobile apps, ways of manufacturing mobile apps, rapid development of mobile network, and so on, and hardly mentioned the factors determining the usefulness of mobile applications (Kang, 2014). With the popularity, wide use and influence of mobile applications on people, especially students, researching on these factors has become pertinent (Kang, 2014).

Mobile Application: Mobile applications according to Liu, Zhang, Ye and Liu (2017) are applications running on mobile devices with apps. These devices have become a major information and services carrier. Liu et al, also posit that apps are applications on mobile intelligent terminal equipment. For Gahran (2011), mobile apps are tools that were originally used in carrying out certain activities, until the era of smartphones when people started using "app" to refer to software. Normally, apps are downloaded from application distribution platforms which are operated by the owner of the mobile operating system, such as Google Play Store (Carey, 2015). Mobile learning or educational app, which is one kind of apps, mainly involves the content of study, reading, examination, entertainment, finances and a lot more (Leyden, 2015). Recently, the number of people using mobile technology devices has reached to very high levels (Ozcinar, Ekizoglu \& Kanbul, 2015).Additionally, Dogtiev (2019) went on to postulate that major smartphones and tablet producers use manufacturing of regular hardware updates and introduction of brand new features to promote the growth of mobile applications. Noticeably, the use of mobile application contributes to the School and family education growth pattern. Therefore, the education market, which has a large number of users who are mainly college students, has tremendous growth potential and a college student-focused learning app (Robust Tech House, 2017).

Mobile Educational or Learning Application: According to Odia and Omofonmwan (2007), education is the bedrock of development, and the growth of any society is dependent on the level of education of its citizens. Consequently, a society that disregards education ends up producing unqualified graduates who are educated illiterates (Lehmann, 2018). There are tools used to support and facilitate learning and mobile educational or learning applications are part of these important learning tools (Eady \& Lockyer, 2013). Mobile phones are no longer the ordinary communication device, they are now made in such a way that teachers can conduct their normal classes without having to be in the physical classroom and are also used widely in education to enhance teaching and learning and the development of skills (Harnil, 2017). Harnil (2017) also posit that mobile educational applications have made distant learning possible and easy. According to Mareco (2017) in a traditional classroom, learners are passive most often because they are meant to listen and assimilate whatever the teacher teaches, thus, making students' physical presence very important. Mareco (2017) went on to assert that these applications are growing rapidly and can be used for various purposes such as for individuals, personal entertainment and task performances. According to Orehovački and Babić (2015) the wide use of mobile devices such as tablets in day to day living encourages the use of mobile applications in the educational process which is seen as a new educational Standard. Albarran (2009) carried out a study about the uses and gratifications of mobile phone use in a cross-cultural analysis and found that communication, instrumental use (video/photo sharing), and entertainment (boredom relief) were the top three motivations.

Usefulness of Mobile Educational or learning Applications: Liu et al. (2017) posit that Smart mobile terminals, such as smartphones, IPads and tablets, have become a requirement in the life of students with the highspeed growth of the mobile Internet. These gadgets have helped students to benefit from other peoples' experiences which help them to excel in their various endeavors. Mobile learning apps give learners the freedom and ample time to study anytime and anywhere through mobile intelligent terminals, which improves significantly the suitability of their interest (Liu et al., 2017). According to Smith (2018) people would hardly live a moment without mobile application apps, because of their habits of using mobile apps for regular and basic work. Therefore, Smith is of the opinion that using mobile educational apps in teaching and learning is the biggest benefits for improving child 
capabilities and brain power. Barman (2015) postulate that there are lots of benefits users could get from educational mobile apps as in recent years, most of the educational apps has become interactive and very helpful for the teacher to teach, students to interact and parents to monitor. Furthermore, Anchal (2016) believed that the education sector is now highly reliant on technology. This can be seen in all aspects of education; blackboards and chalk are been replaced with smart boards, interactive board, learning management systems such as Edmodo and Google classroom platforms (Menezes, 2012). Hence, technology through mobile educational application promotes easy communication between students and teachers and students are able to learn difficult topics easily while teachers are teaching in interactive and fun ways, involving the students on to those activities they actually want (Mustafa, 2016). On this note, users can easily share, collaborate and connect with other users of the app or website and share messages, favorites, and notes for their own enrichment, as well as have the opportunity to use educational tools such as language learning and examination (OSXDaily, 2016).

Factors that Determine the Usefulness of Mobile Educational Applications: Mobile applications are used for various purposes and are beneficial to peoples of all ages. Smith (2018) explained that educational applications for competitive examination are one the best type that will help those who are preparing for competitive exams. Nevertheless, there are certain factors that could prevent an individual from enjoying the full potential of mobile educational applications. One of these factors is the quality and reliability of the application (Lui et al., 2017). Lui et al. assert that part of the faults that exist in mobile learning apps include Boring fabrics, conceptual uncertainty and poor quality that have not been planned and produced from the point of view of user satisfaction. Some of the apps are often inactive and which acts as a hindrance or distraction towards acquiring the help students and other users might need (Clark, 2011). Hence, for any mobile application to be useful, it has to contain the important and viable features that will help the users to benefit from its potentialities (Nitin, 2015). Likewise, mobile educational applications have very rich, attractive and engaging contents which help users to remain focused while using them. That means that when mobile applications are being used to enhance teaching and learning, it is important for the users to be focused and undistracted, so as to benefit from them (Akporum, 2015). According to Roy (2017), it has been discovered that not every student can assimilate knowledge while he or she is busy with other things. Roy went on to emphasize that it is important to ensure that a student's focus is only on one thing at a time while making use of the mobile educational applications, so as to make learning more engaging and fruitful (Roy, 2017). Therefore, in a school environment, proper monitoring of students over the use of mobile applications would help them to profit from them (Kumar, 2015). Similarly, gender, computer self-efficacy, and levels of training (competency) are also used to predict technological usage (Mugo, Njagi, Chemwei \& Motanya, 2017). Another way to ensure an app have optimal performance on any given device is to develop the app natively for a particular device. Developing an appropriate mobile application compactible for various phones is important (Harnil, 2017). Payne, Lister, West, and Bernhardt (2015) posit that learning the procedures or guidelines for the use of mobile educational apps is necessary for its functionality. This means that every user of mobile educational application must first of all learn how they are used in order to make maximum use of it.

Theory of Planned Behaviors: The research reviews the use of "Theory of Planned Behavior" (TPB). This theory was developed by Ajzen (2012). The theory proposed a model in order to measure how human actions are guided. It is a major framework for understanding, predicting and changing human social behavior (Lawali \& Bashir, 2015). According to the theory, intention is the immediate precursor of behavior and is in itself a function of attitude toward the behavior. The TPB is used to forecast factors that explain the usefulness of mobile educational applications and factors that determine its usefulness. The intention of an individual to carry out diverse kinds of action can be determined with great attitudes that are accurate towards the performance, idiosyncratic norms, and control of behavior which is capable of explaining the intentions, together with insights of behavioral control, and description for considerable variance in actual behavior (Ajzen, 2012). Hence, the usefulness of mobile educational apps partly depends on the attitude of the user. This can either make or mare the usefulness of mobile educational or learning apps.

Social Cognitive Theory: Social cognitive theory was advanced by Albert Bandura in 1977 as an extension of his social learning theory (LaMorte, 2018). The theory is These mechanisms are central to understanding personality, based on the principles that people learn from seeing what others do and do not do. Theorists of social cognitive theory accept the fact that there are some influences on development created by learned behavior exhibited in the environment in which an individual grows up. They trust that an individual is significant in determining moral development. Social cognitive theory is related to this review (factors determining the usefulness of mobile educational apps) in the sense that, human beings do not learn new behaviors merely by trying them, but the survival of an individual depends on the replication of the actions of others (Vinney, 2019 ).

Technology Acceptance Model (TAM): Technology acceptance model was developed by Fred Davis in 1989 (Mugo, Njagi, Chemwei \& Motanya, 2017). It is a commonly used model to measure technology acceptance and proposes that when users are presented with a new technology, user's decisions about how and when they will use it are being determined by a number of factors such as perceived usefulness (how much the user believes that the technology will help to improve their performance) and perceived ease of use (refers to what extent the user is comfortable in using the features of the technology) (Mugo, Njagi, Chemwei \& Motanya, 2017). Perceived usefulness is being influenced by certain variables (internal) such as 
attitude of the user, their didactic beliefs, and level of competency, and external variables such as those external Barriers that users face during use. Organizational obstacles, technical barriers and social barriers are such factors. (Saleh \& Drew, (2014) in Mugo, Njagi, Chemwei, \& Motanya, 2017). TAM model is relevant to this study (a review of factors determining the usefulness of mobile educational aps) because the above mentioned internal and external factors also influence the usefulness of mobile educational apps.

The three theories explain how users can determine the usefulness of mobile educational applications by their behavior and intention and decisions, together with external factors. The theory of planned behavior was used by most of the authors to explain how the intention of an individual plays an important role in the use of mobile educational applications. A few literatures used the social cognitive theory. The cognitive theory asserts that the human person learns through observation, which takes place within the environment, hence behavior, and the ability to comprehend things are the important factors that influence Evolution. These three factors are not static or independent elements; in a process of triadic reciprocal determinism, they affect each other instead. (Unnati, 2015). Technology acceptance model points to users' intention and decision as important factors in mobile learning. Therefore, these theories provide useful information on the usefulness and factors determining the usefulness of mobile educational apps.

Review of Past Studies: Harnil (2017) likened the presence of mobile apps on phones with that of the decorations on a cake because they make mobile phones enjoyable and useful. Mobile apps are unlimited. A recent national survey about mobile app estimates that 185 billion apps would have been downloaded by 2014 (Kang, 2014). According to Jayne (2013) mobile applications is of recent becoming more educationally oriented. Mobile educational applications are used to engage the learner to help him or her understands what is being taught as well as attains certain educational objective. This is similar to the opinion of Sayan (2017) who in examining the concept of usefulness, asserts that usefulness is a quality or qualities of a particular person or thing that helps an individual in certain situations, and lack of it is also realized when an individual require assistance. Therefore, in terms of mobile educational or learning applications, there is need to examine the factors that determine their usefulness. Mobile educational applications are widely used in education for various purposes such as getting quick answers to mathematics questions, improving English vocabulary, and lot more (Will, 2018).

Mobile learning works by incorporating a range of hardware and software technologies into multimedia applications, according to Alqahtani and Mohammad (2015), to promote the comprehension of educational content, such as in the form of quizzes or games. There are some mobile educational applications that are free, while others are not (Kang, 2014). Liu, Zhang, Ye, and Liu (2018) emphasize that learning content, including the latest learning materials and the materials occurring in the process of use, is in favor of improving the users' trust in mobile learning apps. This is because The learning material is sophisticated and brief. Therefore, it is Students may help students use fragmented time to learn. Mobile learning offers great opportunities to users, especially in the area of higher education (Alrasheedi \& Capretz 2018). Alrasheedi and Capretz (2018) also posit that the most important perceived advantages of mobile learning from learner perspectives include collaboration during studies. Hence, mobile devices and apps help students in various locations to interact with fellow students and educators even without being in a formal classroom. For the effective use of mobile educational or learning apps, Liu, Zhang, Ye, and Liu (2018) postulate that there is need for the learning content of mobile educational apps to The starting point of learning, learning motivation, and learning style of the users are thoroughly considered. According to Normalini, Lurudusamy \& Arokiasamy (2017), easy use of mobile educational apps is an important predictor towards intention to use technology on a general basis. In order words, learning content should be directed towards the users' learning rule and characteristics.

In the papers reviewed, it could be seen that factors determining the usefulness of mobile educational apps are mostly neglected. Hence, it is penitent to bring to light, various factors that determine the usefulness of mobile educational apps so as to sustain their usefulness which includes enhancement of teaching and learning.

\section{METHODOLOGY}

In order to identify the existing literature that deals with factors determining the usefulness of mobile educational or learning applications, this study used systematic literature review approach according to Kitchenham (2004) to search for the relevant journals and other works on the usefulness of mobile educational applications and factors that determine their usefulness respectively. Likewise, this systematic review was carried out based on the restrictions defined by Kitchenham (Kitchenham, 2004; Mkpojiogu \& Asuquo, 2018). The following are the activities in the systematic review: The first stage which is planning the review, second stage is conducting the review and finally, the result presentation.

Planning the Review The goal was to gather important and sufficient data on the usefulness and factors that decide the usefulness of mobile apps for education or learning. As the primary search in this respect, the search and selection strategy was established. The primary search was performed using Internet databases for high-level journals and conference proceedings in the field of the factors determining the usefulness of mobile educational apps. In this regard, the researchers categorized the strategy for search and selection As a secondary and primary search. The primary search was carried out for highly ranking articles and conference papers based on the field of Internet databases factors determining the usefulness of mobile educational apps. The secondary search was carried out through citation and references gotten in the course of the 
primary search. However, prominent emphasis was given to relevant studies ranging from the year 2004 to 2019. This provided current issues on the factors determining the usefulness of mobile educational apps. However, literatures on the factors determining the usefulness of mobile educational apps were limited. Hence, table 1 includes selected journal and conference papers, the number of papers per journal and the year of publication.

Table 1: Selected Journal, Articles and Conference Proceedings and Number of Papers

\begin{tabular}{|l|l|}
\hline Journal & $\begin{array}{l}\text { No. of } \\
\text { Papers }\end{array}$ \\
\hline $\begin{array}{l}\text { World Journal on Educational Technology } \\
\text { (WJET) }\end{array}$ & 1 \\
\hline Journal of Universal Computer Science (JUCS) & 1 \\
\hline $\begin{array}{l}\text { The Turkish Online Journal of Educational } \\
\text { Technology (TOJET) }\end{array}$ & 1 \\
\hline $\begin{array}{l}\text { International Research Journal of Electronics \& } \\
\text { Computer Engineering (IRJECE) }\end{array}$ & 1 \\
\hline JMIR M health U health & 1 \\
\hline $\begin{array}{l}\text { International Journal of Mobile Communications } \\
\text { (IJMC) }\end{array}$ & 1 \\
\hline The Journal of Knowledge Management (TJKM) & 1 \\
\hline $\begin{array}{l}\text { International Journal of Engineering and } \\
\text { Techniques (IJET) }\end{array}$ & 1 \\
\hline $\begin{array}{l}\text { Organizational Behavior and Human Decision } \\
\text { Processes (OBHDP) }\end{array}$ & 1 \\
\hline Journal of Research in National Development & 1 \\
\hline $\begin{array}{l}\text { British Journal of Mathematics \& Computer } \\
\text { Science }\end{array}$ & 1 \\
\hline $\begin{array}{l}\text { International Academic Journal of Science and } \\
\text { Engineering (IAJSE) }\end{array}$ & 1 \\
\hline 2013 ASEE Southeast Section Conference & 1 \\
\hline Articles (Google search) & 30 \\
\hline $\begin{array}{l}\text { TOTAL NO. of Journals, Articles and } \\
\text { Conference Proceedings }\end{array}$ & 43 \\
\hline
\end{tabular}

For both journals and conference proceedings, the collection of appropriate papers focused more on the field of general concept of usefulness of mobile applications, mobile educational or learning applications and the factors determining the usefulness of mobile educational or learning applications and factors determining the usefulness of mobile educational apps. Nonetheless, the system of review was centered on the keywords: usefulness of mobile applications, mobile educational or learning applications. Consequently, some related and appropriate papers have been carefully For efficient analysis and data extraction, picked. The papers chosen for the study were obtained from the following journal, conference and articles: International Journal of Mobile Communications, The Journal of Knowledge Management, IJET, World Journal on Educational Technology, The Turkish Online Journal of Educational Technology, Journal of Universal Computer Science, International Research Journal of Electronics and Computer Engineering, International Journal on New Trends in Education and Their Implication, and Google Search.
Conducting the Review: In this step, the selected papers were downloaded using the search string of the report, and the abstract of each was carefully read to examine its relevance to this study. Seventy-eight (78) works were downloaded from journals, and conference proceedings. However, only relevant papers with significant contributions were selected for further reading, as such only forty-three (43) papers were considered. The 43 papers that were then selected were carefully read, and studied to gain relevant details that relate to the subject matter of the review. Important and needful information (related to factors determining the usefulness of mobile educational apps) were To be extracted, gathered and summarised. These provided the basis for the analysis described in the section on the findings. The complete list of papers selected is shown in Table 2. From 2004 to 2019, these selected papers were shielded. These papers offered a good coverage of information technology literature collected after a detailed selection of the 78 papers downloaded on the subject matter of the study.

Table 2: List of Selected Papers

\begin{tabular}{|l|l|l|}
\hline Paper ID & \multicolumn{1}{|c|}{ Authors } & Year \\
\hline EA1 & Clark, J. & 2011 \\
\hline EA2 & Eady, M. J., \& Lockyer, L & 2013 \\
\hline EA 3 & Anchal, M. & 2016 \\
\hline EA 4 & OSX Daily & 2016 \\
\hline EA 5 & Barman, S. & 2015 \\
\hline EA 6 & Rouse, M. \& Damian, J. & 2013 \\
\hline EA 7 & Smith, P. & 2018 \\
\hline EA 8 & Gundala, S. & 2016 \\
\hline EA 9 & Graham, A. & 2011 \\
\hline EA 10 & Harnil, O. & 2017 \\
\hline EA 11 & Dogtiev, A. & 2019 \\
\hline EA 12 & Kitchenham, B. & 2004 \\
\hline EA 13 & Orehovacki, T., \& Babic, S. & 2015 \\
\hline EA 14 & Roy, S. & 2017 \\
\hline EA 15 & Odial, I., Omofonmwan, J. & 2007 \\
\hline EA 16 & Nitin, D. & 2015 \\
\hline EA 17 & Robust Tech House & 2017 \\
\hline EA 18 & Sayan, M. & 2017 \\
\hline EA 19 & Jayne, C. & 2013 \\
\hline EA 20 & Menezes, P. & 2012 \\
\hline EA 21 & Leyden, A. & 2015 \\
\hline EA.22 & Carey, R. & 2015 \\
\hline EA 23 & Kumar, S. & 2015 \\
\hline EA 24 & Mareco, D. & 2017 \\
\hline EA 25 & $\begin{array}{l}\text { Normalini, M.K., Lurudusamy., } \\
\text { \& Arokiasamy }\end{array}$ & 2017 \\
\hline EA 26 & Alrasheedi, M., \& Capretz, F. & 2018 \\
\hline EA 27 & LaMorte, W. & 2018 \\
\hline EA 28 & Lehmann, C. & 2018 \\
\hline EA 29 & Mkpojiogu, E.O.C., \& Asuquo, & 2018 \\
\hline EA 30 & Mugo, D., Njagi, K., Chemwei, & 2017 \\
& B., \& Motanya, J & \\
\hline & & \\
\hline
\end{tabular}




\begin{tabular}{|l|l|l|}
\hline EA 31 & 2015 \\
\hline EA 32 & Unnati, S. & 2019 \\
\hline EA 33 & Ajzen, I & 2012 \\
\hline EA 34 & Akporum, D. & 2015 \\
\hline EA 35 & Alqahtani, M., \& Mohammad, H. & 2015 \\
\hline EA36 & $\begin{array}{l}\text { Buck, J., McInnis, E., \& } \\
\text { Randolph, C }\end{array}$ & 2013 \\
\hline EA 37 & Kang, S & 2014 \\
\hline EA38 & $\begin{array}{l}\text { Liu. L., Zhang. L., Ye. P. \& Liu. } \\
\text { Q. }\end{array}$ & 2018 \\
\hline EA39 & Lawali, Y., \& Bashir, I. & 2015 \\
\hline EA40 & Mustafa, H . & 2016 \\
\hline EA41 & $\begin{array}{l}\text { Ozcinar, Z., Ekizoglu N., } \\
\text { \&Kanbul, S }\end{array}$ & 2015 \\
\hline EA 42 & $\begin{array}{l}\text { Payne, H., Lister, C., West, J., \& } \\
\text { Bernhardt, J. }\end{array}$ & 2015 \\
\hline EA43 & Will, N. & 2018 \\
\hline
\end{tabular}

These factors influence users' effective use as well as the usefulness of mobile educational apps. The percentage of research papers in areas of usefulness of mobile educational or learning apps and factors determining the usefulness of mobile educational apps reviewed literature are shown below.

Table 4: Usefulness of Mobile Educational or Learning App

Different databases have been used to carry out this study, such as Academia.edu, Google Search, Global Academic Community, Research Gate, and Google Scholar. A total of 78 articles were contained in the five databases used and 43 articles were eventually chosen for the research work. The individual databases consulted and the total number of papers found and selected are shown in Table 3 below..

Table 3: Databases and Selected Articles

\begin{tabular}{|l|l|l|l|}
\hline Data Base & $\begin{array}{l}\text { No. of } \\
\text { Article } \\
\text { Found }\end{array}$ & $\begin{array}{l}\text { Articles } \\
\text { Selected }\end{array}$ & Percentage \\
\hline $\begin{array}{l}\text { Global } \\
\text { Academic } \\
\text { Group }\end{array}$ & 4 & 1 & 2.3 \\
\hline Google Scholar & 30 & 16 & 37.2 \\
\hline Academia.edu & 12 & 9 & 20.9 \\
\hline Google Search & 23 & 10 & 23.2 \\
\hline Research Gate & 9 & 7 & 16.2 \\
\hline Total & 78 & 43 & \\
\hline
\end{tabular}

Exclusive criteria and inclusive criteria: The study also used exclusive criteria to remove some key factors not relevant to the study and presented some inclusive criteria in order to concentrate on topics with useful knowledge for the purpose of this paper. The two criteria used are as follows: 1) Exclusive Criteria: a) Reliability of the application; b) Important and viable features of the mobile application; c) Faults that exist in mobile educational apps; 2) Inclusive Criteria: a. Mobile application. b. Usefulness of mobile educational apps.

\section{RESULT AND DISCUSSION}

The selected papers were carefully reviewed and the results of the factors determining the usefulness of mobile educational apps were generated Consequently. This portion of the paper presents the conclusions of the study of the usefulness of mobile educational apps, and the factors determining the usefulness of mobile educational apps.

\begin{tabular}{|c|c|c|c|}
\hline $\begin{array}{l}\text { Usefulness } \\
\text { Mobil of } \\
\text { Educational } \\
\text { Apps }\end{array}$ & Papers & $\begin{array}{l}\text { Frequencie } \\
\mathrm{s} \text { of Studies }\end{array}$ & $\begin{array}{l}\text { Percentag } \\
\text { e }\end{array}$ \\
\hline $\begin{array}{l}\text { Freedom and } \\
\text { Ample Time } \\
\text { to Study }\end{array}$ & $\begin{array}{l}\text { Harnil (2017), } \\
\text { Eady \& } \\
\text { Lockyer } \\
\text { (2013), } \\
\text { Mareco } \\
\text { (2017), } \\
\text { Orehovački \& } \\
\text { Babić(2015), } \\
\text { Menezes } \\
\text { (2012). } \\
\text { Alqahtani and } \\
\text { Mohammad } \\
\text { (2015) }\end{array}$ & 6 & $13.9 \%$ \\
\hline $\begin{array}{l}\text { Easy } \\
\text { Communicatio } \\
n\end{array}$ & $\begin{array}{l}\text { Liu, Zhang, } \\
\text { Ye and Liu } \\
\text { (2017), Harnil } \\
\text { (2017),Marec } \\
\text { o } \\
\text { (2017), } \\
\text { Barman } \\
\text { (2015), } \\
\text { Mustafa, } \\
\text { (2016), }\end{array}$ & 5 & $11.6 \%$ \\
\hline $\begin{array}{l}\text { Teaching and } \\
\text { Learning }\end{array}$ & $\begin{array}{l}\text { Harnil, } \\
(2017) \text {, Eady } \\
\& \\
\text { Lockyer(2013 } \\
\text { ) Mareco } \\
\text { (2017), } \\
\text { Orehovački \& } \\
\text { Babić (2015), } \\
\text { Menezes, } \\
\text { (2012). } \\
\text { Alqahtani \& } \\
\text { Mohammad } \\
\text { (2015), } \\
\text { Robust Tech } \\
\text { House, } \\
\text { (2017), } \\
\text { Gundala } \\
\text { (2016) } \\
\text { (Leyden, 2015 }\end{array}$ & 9 & $20.9 \%$ \\
\hline $\begin{array}{l}\text { Improving } \\
\text { Users' } \\
\text { Potentialities }\end{array}$ & $\begin{array}{l}\text { Gahran } \\
(2011) \text {, Carey, } \\
(2015) \text {. Eady } \\
\& \quad \text { Lockyer, } \\
(2013) \text {, Liu et }\end{array}$ & 5 & $11.6 \%$ \\
\hline
\end{tabular}




\begin{tabular}{|l|l|l|l|}
\hline & $\begin{array}{l}\text { al. (2017), } \\
\text { Smith (2018) }\end{array}$ & \\
\hline $\begin{array}{l}\text { Gaining } \\
\text { insight }\end{array}$ & $\begin{array}{l}\text { Buck, } \\
\text { McInnis \& } \\
\text { Randolph, ( } \\
\text { 2013), } \\
\text { (Leyden, } \\
\text { 2015) }\end{array}$ & & \\
\hline Entertainment & $\begin{array}{l}\text { Mareco } \\
(2017) \\
\text { Albarran } \\
(2009)\end{array}$ & 2 & $4.6 \%$ \\
& & \\
\hline
\end{tabular}

Table 5: Factors Determining the Usefulness of Mobile Educational Apps

\begin{tabular}{|c|c|c|c|}
\hline $\begin{array}{l}\text { Factors } \\
\text { Determining } \\
\text { the } \\
\text { Usefulness of } \\
\text { Mobile } \\
\text { Educational } \\
\text { Apps }\end{array}$ & Papers & Frequencies & $\%$ \\
\hline $\begin{array}{l}\text { Viable } \\
\text { features of the } \\
\text { apps }\end{array}$ & Harnil, (2017) & 1 & $1.3 \%$ \\
\hline Self-efficacy & $\begin{array}{l}\text { Mugo, Njagi, } \\
\text { Chemwei, } \quad \& \\
\text { Motanya, (2017) }\end{array}$ & 1 & $1.3 \%$ \\
\hline $\begin{array}{l}\text { User's } \\
\text { intention }\end{array}$ & $\begin{array}{lr}\text { Ajzen } & (2012), \\
\text { Mugo, } & \text { Njagi, } \\
\text { Chemwei } & \& \\
\text { Motanya,(2017) }\end{array}$ & 2 & $4.6 \%$ \\
\hline $\begin{array}{l}\text { Proper } \\
\text { monitoring }\end{array}$ & $\begin{array}{l}\text { Kumar, 2015). } \\
\text { (Roy, 2017), Payne, } \\
\text { Lister, West, \& } \\
\text { Bernhardt (2015), }\end{array}$ & 3 & $6.9 \%$ \\
\hline Being Focused & $\begin{array}{l}\text { Akporum, (2015), } \\
\text { Roy (2017) }\end{array}$ & 2 & $4.6 \%$ \\
\hline $\begin{array}{l}\text { Mobile } \\
\text { devices }\end{array}$ & $\begin{array}{l}\text { Orehovački } \\
\text { Babić (2015) }\end{array}$ & 1 & $1.3 \%$ \\
\hline
\end{tabular}

Additionally, the results obtained from the selected literatures indicates that studies that captured the areas of usefulness of mobile educational apps in terms of freedom and ample time to study was $13.9 \%$, easy communication $11.6 \%$, teaching and learning $20.9 \%$, improving user potentialities $11.6 \%$, gaining insight $4.6 \%$, and entertainment $4.6 \%$ as shown in Table 4 . Table 5 reveals that the study reviewed to extract factors determining the usefulness of mobile educational application in terms of viable features of apps was $1.3 \%$, self-efficacy $1.3 \%$, user's intention $4.6 \%$, proper monitoring $6.9 \%$, being focused $4.6 \%$, mobile devices $1.3 \%$. Mobile phones are no longer the ordinary communication device because of the mobile educational apps. These applications have made great impact in teaching and learning of various courses and subjects as shown in tables 4. They also make the teaching profession less demanding. Mobile educational apps have improved communication among people especially in school settings. In terms of improving user's potentialities, gaining insight and entertainment as shown also in table 4, mobile educational apps help users to improve their capabilities in learning. The apps have very rich and attractive features that entice users to learn more. Some users also use them as a means of relaxation as well as a way of emitting frustrations. In addition, for users to enjoy the full potentialities of mobile educational apps, the apps, as well as the devices need to be worthwhile as indicated in table 5 , in order to serve the intention for which they were produced. There is need for users to be determined to use them as well as understand the operative skills of the apps. These will help to maximize the benefits of the use of mobile apps. Proper monitoring as well as being focused is part of the requisites for benefiting from the mobile educational or learning apps.

\section{CONCLUSION AND RECOMMENDATION}

Seemingly, there are a number of literatures concerning the usefulness of mobile educational apps, and very few literatures on factors determining the usefulness of mobile educational apps. This paper was aimed at reviewing the usefulness of mobile educational apps and to ascertain the various factors determining the usefulness of mobile educational applications. A systematic analysis was employed to achieve the specified goal. Pertinent posts on the usefulness of mobile educational apps and factors determining the usefulness of mobile educational apps By means of the systematic review protocol, they were chosen. Seventy-eight (78) works were downloaded, but ultimately only forty-three (43) were chosen. All the selected papers were carefully read in order to obtain the expected results that answered the research questions and that are based on the objectives of the study. From the analysis, the results indicate the following: mobile educational apps are very useful in facilitating teaching and learning process, freedom and ample time to study, communication, improving user's potentialities, and entertainment. Furthermore, there are factors that enhance or facilitate the use of theses apps such as viable features of the apps and devices, the quality and reliability of the app, proper monitoring of students, selfefficacy, being focused and user's intention. Nevertheless, there are limitations as regards the number of selected literatures examined. The literatures did not also provide sufficient factors determining the usefulness of mobile educational apps, as well as the usefulness of mobile educational apps. Therefore, there is need to further this research and to study more literatures in order to discover more, the factors determining mobile educational apps and the usefulness of mobile educational apps. Empirical studies are also needed. The results from this paper will help educationists, administrators, teachers, parents and policy makers draw more insight on the best strategies used to promote teaching and learning using mobile educational apps. Further studies will focus on discovering more factors that determine the usefulness of mobile educational apps. 


\section{REFERENCES}

[1] Ajzen, I. (1991). The theory of planned behavior. Organizational Behavior and Human Decision Processes, 50(22), 179-211.

[2] Akporum, D. (December, 2015).Using mobile phones to enhance teaching and learning in developing countries. The Journal of Knowledge Management, 33 (1), 1-12.

[3] Alqahtani, M., \& Mohammad, H. (2015). Mobile applications' impact on student performance and satisfaction. The Turkish Online Journal of Educational Technology.14(4), 102-104

[4] Alrasheedi, M., \&Capretz, F. (January, 2018). Determination of critical success factors affecting mobile learning: A meta-analysis approach. Retrieved fromhttps://arxiv.org/abs/1801.04288

[5] Anchal, M. (2016). What are the benefits of educational mobile apps? https://www.quora.com/What-are-thebenefits-of-educational-mobile-apps-Is-there-awebsite-that-can-help-me-build-one

[6] Barman, S. (2015). What are the benefits of educational mobile apps? https://www.quora.com/What-are-thebenefits-of-educational-mobile-apps-Is-there-a-websitethat-can-help-me-build-one

[7] Buck, J., McInnis, E., \& Randolph, C. (2013). The New Frontier of Education: The Impact of Smartphone Technology in the Classroom. A paper presented at American Society for Engineering Education (ASEE) Southeast Section Conference, Retrieved from http://se.asee.org/proceedings/ASEE2013/Papers2013/1 77.PDF

[8] Carey, R. (July, 2015). Electronic Recollections. Retrieved from https://appstorey.com/2015/07/17/electronicrecollections-by-ricard-carey/

[9] Clark, J. (2011). History of Mobile Applications:Theory and Practice of Mobile Applications. Retrieved from http://www.uky.edu/ jclark/mas490apps/History\%20of $\%$ 20Mobile\%20Apps.pdf)

[10] Dogtiev. A. (2019). App Download and Usage Statistics 2018. Retrieved on May 1, 2019 from http://www.businessofapps.com/data/app-statistics/

[11]Eady, M and Lockyer, L .(2013). Tools for learning: technology and teaching strategies: Learning to Teach in the Primary School,Queensland University of Technology, Australia. Retrieved from ro.uow.edu.au/cgi/viewcontent.cgi article=1413\&contex $\mathrm{t}=$ asdpapers

[12] Ghani, A.B.A., Kaliappen, N., Jermsittiparsert, K. (2019). Enhancing Malaysian SME Employee Work Engagement: The Mediating Role Of Job Crafting In The Presence Of Task Complexity, Self-Efficacy And Autonomy. International Journal of Innovation, Creativity and Change, 6 (11), pp. 1-18.

[13] Gahran, A. (2011). What's a mobile app? Retrieved from http://www.contentious.com/2011/03/02/whats-amobile- app/

[14] Gundala, S. (June, 2016). Education systems around the world: a comparison. Retrieved from https://www.linkedin.com/pulse/education-systemsaround-world-comparison-sashi-gundala.

[15] Harnil, O. (2017). The importance of mobile applications in everyday life!

[16] https://appstorey.com/2015/07/17/electronicrecollections-by-ricard-carey/

[17] Hussein, I., Hussain, A., Mkpojiogu, E.O.C., \& Nathan, S.S. (2019). The state of user experience design practice in Malaysia. International Journal of Innovative Technology and Exploring Engineering, 8(8S), 491-497.

[18] Hussain, A., Hussein, I., Mkpojiogu, E.O.C., \&Sarlan, A. (2019). The state of user experience design (UXD) practice in Malaysia: an in-situ interview approach. International Journal of Innovative Technology and Exploring Engineering, 8(8S), 498-505.

[19] Hussain, A., \& Mkpojiogu, E.O.C. (2017). Predicting the perceived worth of software products requirements with customer satisfaction. Advanced Science Letters. 23(5), 4269-4273.

[20]Hussain, A., Mkpojiogu, E.O.C., \&Nawi, M.N.M. (2017). Capturing customer satisfaction and dissatisfaction in software requirements elicitation for features in proposed software systems. Journal of Engineering and Applied Sciences (JEAS), 12(21), 5590-5597

[21] Hussain, A., Mkpojiogu, E.O.C. \& Yusof, M.M (2016). Perceived usefulness, perceived ease of use, and perceived enjoyment as drivers for the user acceptance of interactive mobile maps. Proceedings of the $1^{\text {st }}$ International Conference on Applied Science and Technology (ICAST'16), Kedah, Malaysia. AIP Conf. $\begin{array}{lll}\text { Proc. } & 1761 & \text { (1). }\end{array}$ http://dx.doi.org/10.1063/1.4960891.

[22] Jayne, C. (2013). Defining an educational app with jayneclare of teachers with apps. Retrieved from https://www.teacherswithapps.com/blog-defining-aneducational-app-with-jayne-clare-of-teachers-with-apps/

[23] Kang, S. (2014). Factors influencing intention of mobile application use. International Journal of Mobile Communications, 12(4), 360-379.

[24] Kitchenham, B. (August, 2004). "Procedures for performing systematic reviews". Keele, UK, Keele University. Retrieved http://www.it.hiof.no/ haraldh/misc/2016-08-22smat/Kitchenham-Systematic-Review- 2004.pdf

[25] Kumar, S. (July, 2015). How to overcome 5 common problems faced by students in eLearning. Retrieved from https://elearningindustry.com/5-commonproblems-faced-by-students-in-elearning-overcome

[26]LaMorte, W. (August, 2018).The Social Cognitive Theory. $\quad$ Retrieved from http://sphweb.bumc.bu.edu/otlt/MPHModules/SB/Behav ioralChangeTheories/BehavioralChangeTheories5.html

[27] Leyden, A. (January, 2015). Why mobile learning apps are the future of education. Retrieved from https://www.goconqr.com/en/examtime/blog/mobilelearning-apps-future-of-education/

[28] Lehmann, C. (May, 2018). Are we graduating too many "educational illiterates"? 
[29] Retrieved from https://canadafreepress.com/article/arewe-graduating-too-many-educational-illiterates.

[30] Liu. L., Zhang. L., Ye. P. \& Liu. Q. (2018). An empirical analysis of china. International Journal of Engineering and Techniques, 18(3), 87-89

[31] Lawali, Y., \& Bashir, I. (2015).Theory of planned behaviour and the use of cell/mobile phone in the classroom. International Research Journal of Electronics \& Computer Engineering, 1(1)

[32] Mareco, D. (July, 2017). 10 Reasons today's students need technology in the classroom. Retrievedfrom.https://www.emeraldinsight.com/doi/abs/ 10.1108/10748120110424816

[33] Menezes, P. (May, 2012). From chalkboards to smart boards? has technology changed the way teachers teach? Retrieved from https://commons.trincoll.edu/edreform/2012/05/fromhalkboards-to-smart-boards-has- technologychanged-the-way-teachers-teach/

[34] Mkpojiogu, E.O.C., \&Asuquo, A. (2018). The user experience of ATM users in Nigeria: a systematic review of empirical papers. Journal of Research in National Development, 16(1) 115-116

[35] Mugo, D., Njagi, K., Chemwei, B., \&Motanya, J. (2017). The technology acceptance model (TAM) and its application to the utilization of mobile learning technologies. British Journal of Mathematics \& Computer Science,20(4), 1-8

[36] Mustafa, H .(2016).Use of mobile application: means of communication between parents and class teacher. World Journal on Educational Technology, 8(3) 252-257

[37] Nitin, D. (2015) Reasons mobile apps are better than mobile websites. Retrieved from https://vwo.com/blog/10- reasons-mobile-apps-arebetter

[38] Normalini, M.K., Lurudusamy, S.N., \&Arokiasamy, L. (2017). Factors that influence mobile application usage among undergraduates in Malaysian public university. International Academic Journal of Science and Engineering, 4(1), 121-133

[39] Odia1, L., Omofonmwan, J. (2007). Educational system in Nigeria problems and prospects. Retrieved from https://www.researchgate.net/publication/305553461_Pe rspectives_of_Academic_Integrity_from_Nigeria

[40] OSXDaily. (2016). How to share notes from Iphone, Ipad, for collaborative editing. Retrieved from osxdaily.com/2016/10/06/share- notes - ioscollaborative.

[41] Ozcinar, Z., Ekizoglu N., \&Kanbul, S. (2015). A study on developing a scale for determining the educational usage of mobile communication apps. Journal of Universal Computer Science, 22(1), 146-158

[42] Payne, H., Lister, C., West, J., \& Bernhardt, J. (2015). Behavioral functionality of mobile apps in health interventions: A Systematic Review of the Literature. JMIR MhealthUhealth, 3(1) 20

[43] Robust Tech House. (2017). Mobile app development. Retrieved from https://robusttechhouse.com/caneducation- sector-benefit-using-mobile- apps/).
[44] Rouse, M \& Denman, J. (December, 2013). Mobile apps. $\quad$ Retrieved from https://searchmicroservices.techtarget.com/definition/mo bile

[45] Roy, S. (2017). Five benefits of using mobile apps in education https://elearningindustry.com/mobile-apps-ineducation-5-benefits

[46] Sayan, M.(2017). What is the difference between 'usefulness' and 'importance'? Retrieved from https://www.quora.com/What-is-the-difference-betweenusefulness-and-importance

[47] Smith, P. (2018).What are the benefits of educational mobile apps? https://www.quora.com/What-are-thebenefits- of-educational-mobile-apps-Is-there-awebsite-that-can-help-me-build-one

[48] Orehovački, T., \&Babić. S. (2015). Qualitative Approach to Determining the Relevant Facets of Mobile Quality of Educational Social Web Applications. https://www.academia.edu/34130800/Qualitative_Appro ach_to_Determining_the_Relevant_Facets_of_Mobile_ Quality_of_Educational_Social_Web_Applications

[49] Unnati, S. (2015). Theories of Development - Life Span Development. $\quad$ Retrieved from https://www.slideshare.net/unnatishah1/theories-ofdevelopment-life-span-development

[50] Vinney,C. (January, 2019). Social Cognitive Theory: How We Learn From the Behavior of Others. Retrieved from https://www.thoughtco.com/socialcognitive-theory-4174567

[51] Will, N. (May 12, 2018). Get smart: The best educational apps for iPhone and Android. Retrieved from https://www.digitaltrends.com/mobile/besteducational-apps 